\title{
Erratum to: Acyclovir resistance in herpes simplex virus type I encephalitis: a case report
}

\author{
M. Bergmann ${ }^{1} \cdot$ R. Beer ${ }^{1} \cdot$ M. Kofler ${ }^{1} \cdot$ R. Helbok ${ }^{1} \cdot$ B. Pfausler ${ }^{1} \cdot$ E. Schmutzhard ${ }^{1}$
}

Published online: 29 June 2017

(C) Journal of NeuroVirology, Inc. 2017

Erratum to: J. Neurovirol. (2017) 23:335-337

DOI 10.1007/s13365-016-0489-5

We apologize for the mistake which slipped through all careful reading and re-reading: it must, correctly, read throughout the entire paper ... foscarnet i.v. $60 \mathrm{mg}$ per kg bodyweight (b.w.), t.i.d.

It is correct that $40 \mathrm{mg} / \mathrm{kg}$ b.w. is the recommended daily dose (Chilukuri and Rosen 2011), but in view of the dramatic clinical and neuro-imaging course we opted for an increased dose carefully monitoring for side effects.

\section{References}

Bergmann M, Beer R, Kofler M, Helbok R, Pfausler B, Schmutzhard E (2017) Acyclovir resistance in herpes simplex virus type I encephalitis: a case report. J Neurovirol 23(2):335-337

Chilukuri S, Rosen T (2003) Management of acyclovir-resistant herpes simplex virus. Dermatol Clin 21:311-320

The online version of the original article can be found at http://dx.doi.org/ $10.1007 / \mathrm{s} 13365-016-0489-5$

\section{E. Schmutzhard}

erich.schmutzhard@i-med.ac.at

1 Department of Neurology, Neurocritical Care Unit, Medical

University Innsbruck, Anichstrasse 35, 6020 Innsbruck, Austria 